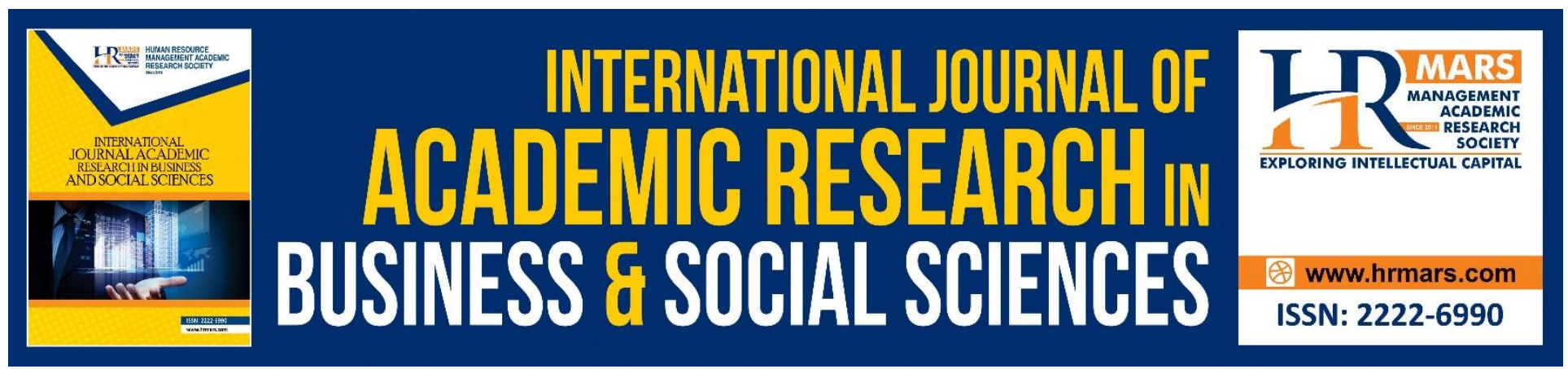

\title{
A Proposed Framework on the Trend of Social Media in School Library
}

Nur Hidayyah Shari Shawarudin and Norhayati Baba

To Link this Article: http://dx.doi.org/10.6007/IJARBSS/v8-i9/4597

DOI: $\quad 10.6007 /$ IJARBSS/v8-i9/4597

Received: 14 August 2018, Revised: 29 August 2018, Accepted: 29 Sept 2018

Published Online: 13 October 2018

In-Text Citation: (Shawarudin \& Baba, 2018)

To Cite this Article: Shawarudin, N. H. S., \& Baba, N. (2018). A Proposed Framework on the Trend of Social Media in School Library. International Journal of Academic Research in Business and Social Sciences, 8(9), 353-363.

Copyright: (C) 2018 The Author(s)

Published by Human Resource Management Academic Research Society (www.hrmars.com)

This article is published under the Creative Commons Attribution (CC BY 4.0) license. Anyone may reproduce, distribute, translate and create derivative works of this article (for both commercial and non-commercial purposes), subject to full attribution to the original publication and authors. The full terms of this license may be seen

at: http://creativecommons.org/licences/by/4.0/legalcode

Vol. 8, No. 9, September 2018, Pg. 353 - 363

http://hrmars.com/index.php/pages/detail/IJARBSS

JOURNAL HOMEPAGE

Full Terms \& Conditions of access and use can be found at http://hrmars.com/index.php/pages/detail/publication-ethics 


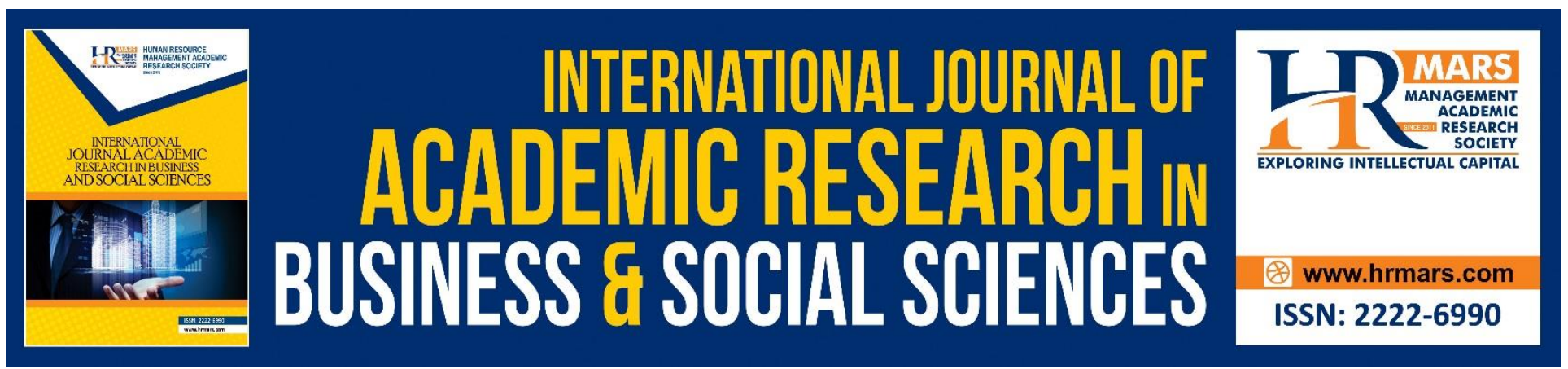

\title{
A Proposed Framework on the Trend of Social Media in School Library
}

\author{
Nur Hidayyah Shari Shawarudin and Norhayati Baba \\ Faculty of Information Management, Universiti Teknologi MARA (UiTM), UiTM Selangor, Malaysia
}

\begin{abstract}
The lack of social media use among school libraries internationally are working to deliver and provide information to users have been increase. The modern method and up to date technology involved the application of social media and other technology tools for more effective library management and can increase library usage rate. International school libraries have made an effort to catch up with this situation by providing a quick information about library. This research aim is to identify the trend of social media in international school library. It is specifically studies on International school library because their schools are more exposed to the use of more modern technology. This research is based on data obtained from a survey questionnaire that polled users experience regarding the social media that has been used in international school libraries. The data was analyzed to evaluate and determine the awareness, ability and implementation of great school library. The research suggested that great school library are linked to marketing of promotion of school library. The result of the study also suggested that a implementation of social media is needed for international school library to build the great school library. It is hope that the study can contribute to the improvement of social media in international school library.
\end{abstract}

Keyword: Social Media, International School, School Library, Library Marketing, Library Promotion

\section{Introduction}

Most international schools in Malaysia use social media as a platform for them to communicate with their users consisting of students, teachers, school staff and parents. Social media can help librarians find new ways to interact and communicate with the school community whether students, staff and parents. Social media can also be defined as a device or platform where the library can use the network to communicate, share information, build or form groups that are networking. It can be seen that the school library in international schools emphasizes the importance and need of a library to users, especially students. Social media apps are not foreign to librarians, especially for libraries at international schools. Social media has become the latest platform in the library to interact and service users virtually. The use of social media within international school libraries is very widespread.

In addition, social media can also help the library in collecting data and information regarding the problems faced by the user when they make a comment or question through a new feed or 
INTERNATIONAL JOURNAL OF ACADEMIC RESEARCH IN BUSINESS AND SOCIAL SCIENCES

Vol. 8, No. 9, Sept. 2018, E-ISSN: 2222-6990 @ 2018 HRMARS

through direct message or email. The library itself usually uses social media as a medium to conduct promotions, either promoting the collection or services offered. The use of social media within the school library is strongly encouraged. The school library is a library within a school where students, staff, and parents of public or private schools have access to a variety of sources. The international school library is a very important portion in a school for users to get accurate and authentic information. This international school meets the needs of students who are not nationals of the host country, such as children of international business staff, international organizations, foreign embassies, missions, or missionary programs.

The library is a natural evolution of library services to the point where library users to control how and when he gets access to the services needed and desired (Brevik, 2006). The International school libraries now have to serve more users comprising of students, parents and staff. The librarians also need to assist the users in teaching and research especially if the school have the students who taking the International Baccalaureate Diploma. In order to fulfill this those need, the school libraries have to upgrade their services, collections, and even the library promotions. Social media can be a powerful information dissemination tool and offers ways for school libraries to promote their activities, resources and services while allowing bilateral dialogue with the user. International school libraries have made an efforts to catch up with this situation by providing a quick information about library. Users can access the information to users with the right time just by using modern method and up to date technology.

The modern method and up to date technology involved the application of social media and other technology tools for more effective library management and can increase library usage rate. Social media provides opportunities to integrate the attendance rate and lending rates of existing materials in school libraries. Social media can be used in a variety of communication methods in general it is used as broadcast messages, feedback to queries and then conversations between institutions and users but without taking into account the approaches taken there is an interesting reason for libraries to engage with social media.

There is a significant lack of social media usage at International School Library. Most of the International School library do not use the social media as a medium of marketing, promotion and etc. The researcher have chosen International school library because their schools are more exposed to the use of more modern technology. The optimal use of social media can support the library to provide the best service to the user. Currently there are many libraries that use social media, but not many libraries that can utilize social media optimally (Luo, Wang, \& Han, 2013).

\section{Literature Review}

\section{The Awareness of Social Media In Promoting Libraries And Information Services}

Social media apps provide a functional setting concept "Mechanical Turk" to enable an app to automatically turn on the visibility of attraction from around the following followers or users to a wider level beyond the visibility of the various backgrounds of social media users around the world. This has given of the user's knowledge of using social media, it provides an opportunity for libraries to attract new users and to keep their users current, thus enabling libraries to become more efficient and significantly affect library performance (Chua and Banerjee, 2013). To prevent this from happening, librarians who control and are responsible for administering social media libraries play a role in monitoring every social media activity provided and ensuring the information and content of social media is always accurate, up to date and in accordance with library services. 
INTERNATIONAL JOURNAL OF ACADEMIC RESEARCH IN BUSINESS AND SOCIAL SCIENCES Vol. 8, No. 9, Sept. 2018, E-ISSN: 2222-6990 @ 2018 HRMARS

The purpose of using social media is to raise awareness, connect with users and actively try to influence users to like and want to use library services. Social media used by school libraries to promote library services and information provided has saved the library staff time and time. Quality of service social media should always be fixed from time to time to review the objectives and establish clear guidelines for providing effective services to users. Library also using social media as a platform to communicate using different ways to different users with greater impact. Social media has helped the school's library in providing quick feedback and updates to users and providing forum space for quick and fast feedback from library users. Using social media for marketing libraries and information services enables broad reach but has a very low cost (Villoldo, 2012). Social media is used as an essential tool for libraries as marketing and intend to increase their users (Choi, N., \& Joo, S., 2018). Social media has enabled libraries to be in a unique position to use them to market services provided by the library (Tagtmeier, 2010). The library should create a name or organization name easily remembered by the social media community or library users.

This is especially supported by the condition that school libraries are one of the organizations that have many social media users in terms of students, teachers and parents. The library can have users and communities and stakeholders to follow them through social media. Given the popularity of social media among consumers, many libraries have also used social media actively to increase marketing and promotion activities (Choi, N., \& Joo, S., 2018). Social media gives variations to librarians whether to establish formal or informal relationships with users. The library may perform actions or activities on social media about products and services without investing a penny. Social media provides librarians with the opportunity to accent themselves to the attention of unpredictable social media users. The social media is an effective tool for library promotion (Hall, $H$., 2011). Most of the users have extensive knowledge of using social media (Fasae, J. K., \& AdegbileroIwari, I., 2016).

\section{The Ability of Social Media in Connecting People and Promoting Understanding}

Social media is not just for communication space but can also be used for the marketing of collections or information offered by the school library (Qualman, 2009). With a successful promotion, users are expected to know the service provided by the devotees to make them interested to visit and utilize library collections and services even it's hard to keep up with the latest social media platforms. The use of social media for social interaction and communication with library users benefits its exploits as a tool to improve library services for libraries. Today, social media in the Library has become an important service for disseminating the latest information and as a platform for users to channel their opinions, queries and concerns. School libraries also create event invitations for programs as an additional forum to promote library activities in social media (Chu \& Meulemans, 2008). Recent research shows that more and more people use social media application like Facebook and Twitters for various reasons such as making new friends, socializing with old friends, receiving information, and entertaining themselves (Kaplan \& Haelein, 2010). One of the primary uses of social media by school libraries is promoting libraries with a home page library website. Given the abundance of social media making librarians who want to market and promote libraries should be good at choosing the best medium for school libraries.

School librarians can adopt social media into their promotional delivery system, and librarians can engage students on social media platforms for promotion purposes to make academic use of student interests in social media (Fasae, J. K., \& Adegbilero-Iwari, I., 2016). This explanation of social media marketing leads us to the other side of marketing, where building relationships with potential 
INTERNATIONAL JOURNAL OF ACADEMIC RESEARCH IN BUSINESS AND SOCIAL SCIENCES Vol. 8, No. 9, Sept. 2018, E-ISSN: 2222-6990 @ 2018 HRMARS

users are the key to repeating arrivals and enhanced loyalty. Maintaining public relations between users and libraries through social media has become easier because of a large number of potential users is available in the virtual network. The use of social media to promote library services, making references to the number of students who use it and the amount of time they spend in (Loving and Ochoa, 2011). The primary motive and perception of using social media are to feel good friends, entertain, maintain relationships, seek information and join the virtual community. Social media marketing to the relationship marketing where libraries need to shift from "trying out" to "establishing a connection" with the user (Gordhamer, 2009). Among professional companies and users outside of librarians, the use of social media has gained high perceptions, acceptance and use for professional and promoting purposes.

Libraries advertise operating hours, website information, recently acquired materials, and etc on social media.

Promotions on social media are made in connection with the status of future developments or events in the library, for example, if new material is added to the collection. Promotions for library promotions are shown in all social media apps but are linked to other records of all institutions. The ease of doing marketing and promotion through social media certainly also encourages the presence and user usage figures. Social media has provided libraries in an innovative and effective way to connect with their users. Library uses social media as a promotional tool to reach the user.

\section{Implementation of the Social Media as a Marketing and Promotion}

The use of social media in libraries serves to listen, respond quickly to users, and provide flexible services that are mobile services, and extend the reach of information access to the public, school librarians also should apply it. With this, the library takes this initiative as a new change to boost their user rates or better known as library 2.0. Users will miss important issues if they do not visit social media by the library (Pierson, V., 2011). Social media in the library usually can be seen that Facebook, Twitter, Instagram, blogs and wikis are but some social networking tools often used in libraries for promotional purposes (Boateng and Liu, 2014). In addition to using social media, reference libraries also provide online services via email and instant messenger that is connected to smartphone applications (Taylor \& Francis Group, 2014). Social media has been used for the promotion of library services to users. With the use of social media is able to make users feel they are members of the library community (Eisend, 2002).

In addition, if social media would be an important platform for communication between librarians and users, both groups need to understand this medium as a useful means of communication. Among the social media that the library can use, including Facebook, Twitter, Youtube, LinkedIn, Tumblr, Pinterest, Instagram, Snapchat. As promotional media, for example, people who are far from the library environment can finally know the existence of the library and little know its profile because it can be viewed through social media. Promotional information on social media used by libraries needs to be more educative and persuasive in the use of non-formal or young language but still polite and civilized. The popularity of social media tools varies from region to region, country to country and even among libraries (Huang et al., 2015). Perceptions on an implementation of social media can be important to understand the use of social media because the behavior can imagine the basic understanding of media as a communications technology platform (Gordhamer, 2009). 
INTERNATIONAL JOURNAL OF ACADEMIC RESEARCH IN BUSINESS AND SOCIAL SCIENCES

Vol. 8, No. 9, Sept. 2018, E-ISSN: 2222-6990 @ 2018 HRMARS

\section{Theoretical Framework}

The framework is a tool analysis with several variations and contexts. It is used to create conceptual differences and organize ideas. The framework captures something real and does this by remembering and applying.

Today, social media is a term that everyone knows. Since the first appearance of social media, it has grown rapidly and is part of an important application for people today. Social media consists of thousands of social media platforms, various types of social media that exist today. Most libraries now prefer to take advantage of this state of the art technology for promotional purposes. Creating a school library promotion through an online presence on the Internet can be a great way to market the service. Internet and communication technology have grown into part of almost every aspect of personal life in everyday life.

\section{Theoretical Review 1}

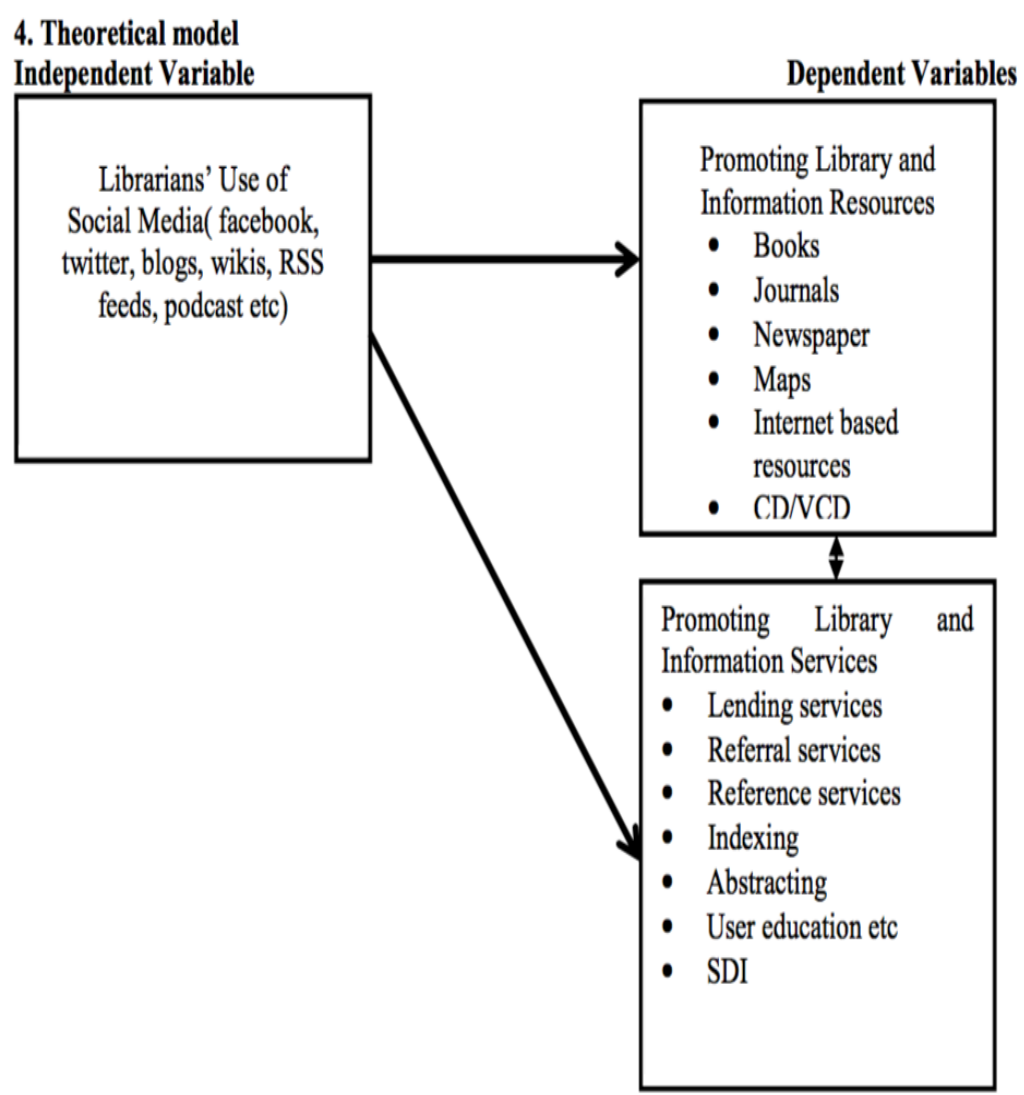

Figure 1 : Framework from “A self designed model for librarians' use of social media to promote library and information resources and services".

The point from literature review is the awareness of social media in promoting libraries and information services. This point is derived from the above framework. This framework is derived from article "A self designed model for librarians' use of social media to promote library and information resources and services (LUSP)". 
INTERNATIONAL JOURNAL OF ACADEMIC RESEARCH IN BUSINESS AND SOCIAL SCIENCES

Vol. 8, No. 9, Sept. 2018, E-ISSN: 2222-6990 @ 2018 HRMARS

\section{Theoretical Review 2}

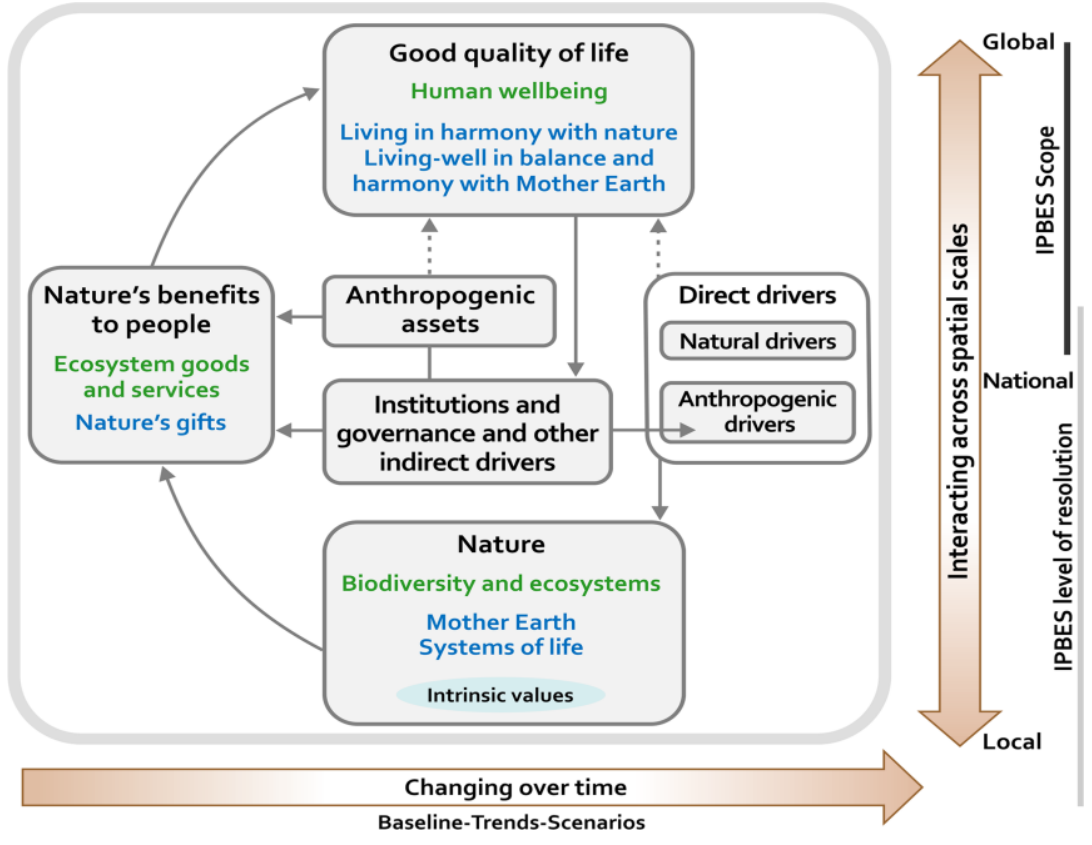

Figure 2 : Framework from A Rosetta Stone for Nature's Benefits to People

The point from literature review is the ability the social media in connecting people and promoting understanding. This point is derived from the above framework. This framework is derived from the article A Rosetta Stone for Nature's Benefits to People. The impact of the most important social media use can certainly connect library users and can promote understanding to users.

\section{Theoretical Review 3}

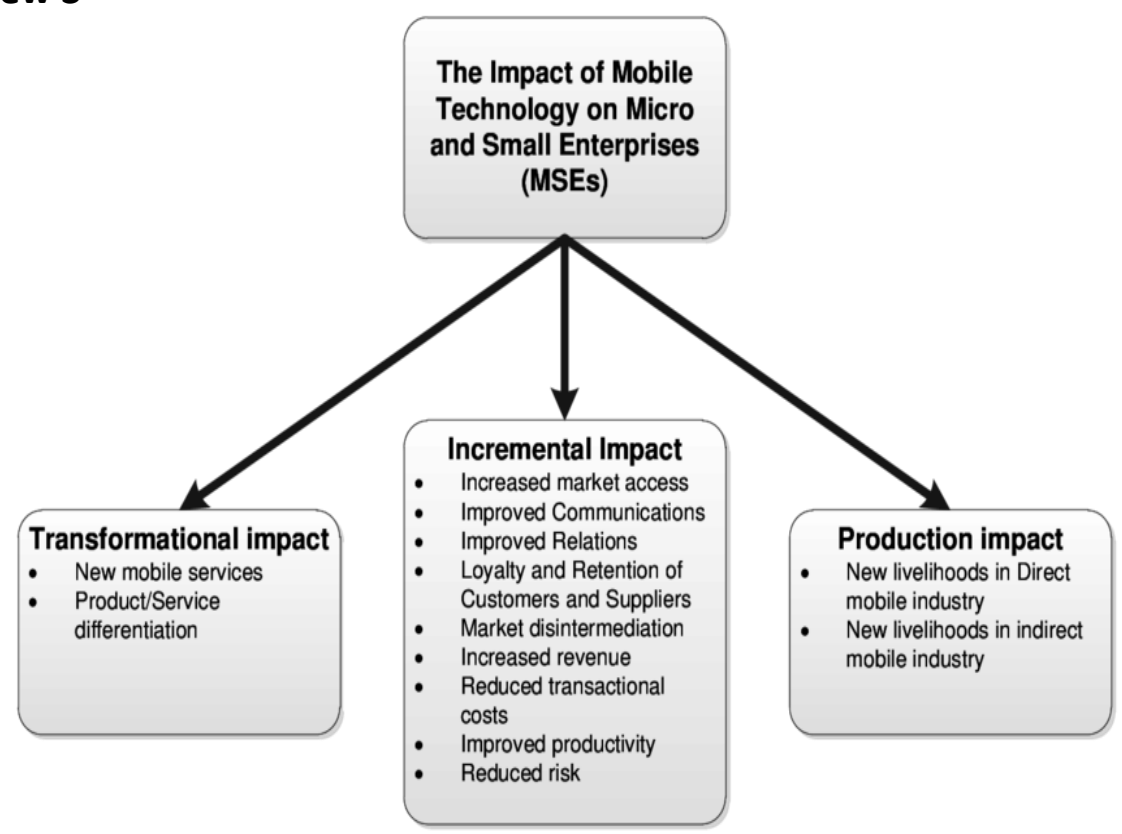

Figure 3: Framework from the impact of mobile technology on Micro and Small Enterprises 
INTERNATIONAL JOURNAL OF ACADEMIC RESEARCH IN BUSINESS AND SOCIAL SCIENCES Vol. 8, No. 9, Sept. 2018, E-ISSN: 2222-6990 @ 2018 HRMARS

The second point from literature review is Implementation of the Social Media as a marketing and promotion. This point is derived from the above framework. This framework is derived from article The Impact of mobile technology on Micro and Small Enterprises. The implementation of Social Media as marketing and promotion can increase the name of the library and promote libraries to users as well as the public to know the collection, and the services provided.

\section{Theoretical framework of relationships Tested the Study}

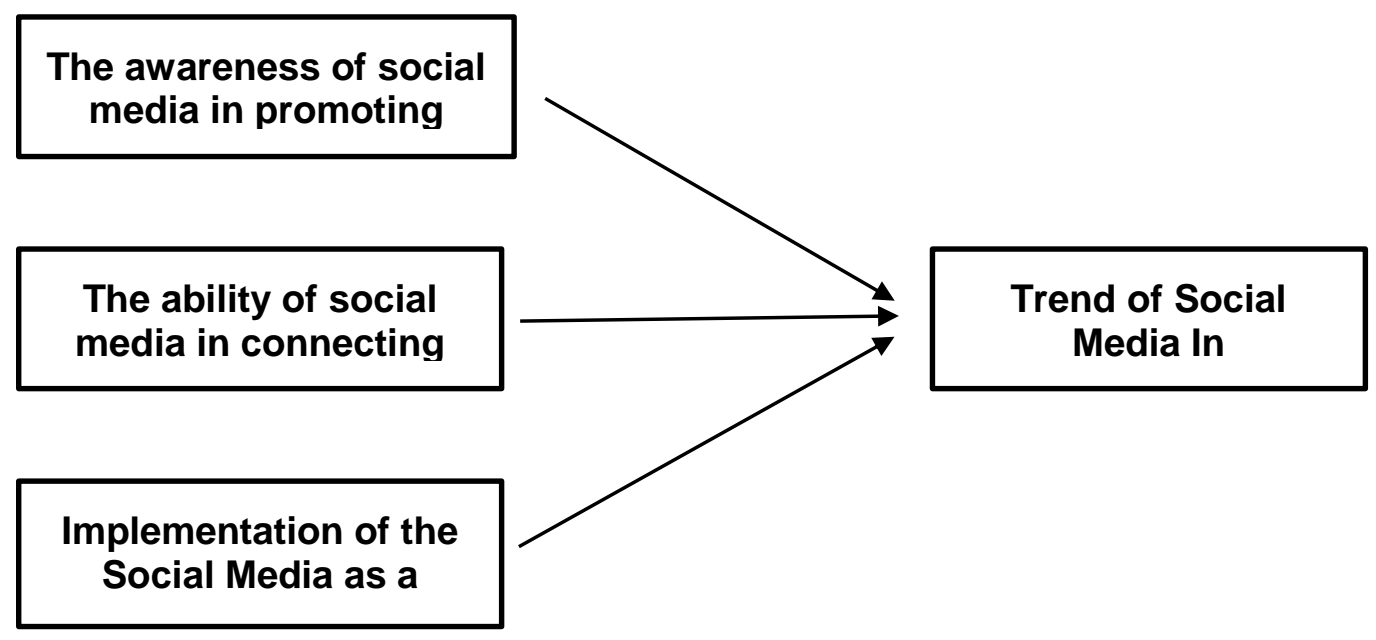

Figure 4 : Theoretical framework of relationships tested in the study

Based on the review, the dependent variable for this framework is Trend of Social Media In International School Library. This shows the trend of social media in international school library as a marketing way to promote school library activities, services and etc. Social media has become part of the platform to be connected with people live today, especially the younger generation in disseminating information, communicating and promoting (Madia, 2011). Three independent variables appear as the most frequently mentioned and considered as a very important point. The independent variable in this framework is the awareness of social media in promoting libraries and information services, the ability the social media in connecting people and promoting understanding and implementation of the Social Media as a marketing and promotion.

\section{Conclusion}

Social media is increasingly accepted by society and has an impact on the school library. Social media is a cheap way to promote libraries to ensure users get information and information about their school libraries. This suggests that for librarians to reach the 21 st users better, communicate better with feedback and adhere to innovation in this computer world, using social media is a must.

\section{References}

Aina, L.O. (2004). Library and information science text for Africa. Ibadan: Third World Information Services Ltd.

Boateng, F. and Quan Liu, Y. (2014), “Web 2.0 applications' usage and trends in top US 
INTERNATIONAL JOURNAL OF ACADEMIC RESEARCH IN BUSINESS AND SOCIAL SCIENCES

Vol. 8, No. 9, Sept. 2018, E-ISSN: 2222-6990 @ 2018 HRMARS

academic libraries", Library Hi Tech, Vol. 3 No. 1, pp. 120-138.

Brummitt, N. and Keeling, A. (2013), "Charting the growth of international schools", in Pearce, R. (Ed.), International Education and Schools: Moving Beyond the First 40 Years, Bloomsbury Academic, London, pp. 25-36.

Canty, N. (2012). Social Media in Libraries: Its Like, Complicated. Alexandria: The Journal of National and International Library and Information Issues, 23(2), 41-54. doi:10.7227/alx.23.2.4

Chauhan, M. (2013), "Use of social media in libraries", available at: www.alibnet.org/bookofpaper/ppts (accessed 1 December 2017).

Choi, N., \& Joo, S. (2018). Understanding public libraries' challenges, motivators, and perceptions toward the use of social media for marketing. Library Hi Tech. doi:10.1108/lht11-2017-0237

Chu, M. \& Meuleman, Y. (2008). The problems and potential of MySpace and Facebook usage in academic libraries. Internet Reference Services Quarterly, 13(1), 69 - 85. Retrieved 13th March 2013 from www.informaworld.com.

Devaus, D. (2002). Bookshelf. Australasian Journal on Ageing, 20(4), 209-213. doi:10.1111/j.1741-6612.2001.tb00388.x

Dickson, A. and Holley, R.P. (2010), "Social networking in academic libraries: the possibilities and concerns", New Library World, Vol. 111 Nos 11/12, pp. 468-479.

Eisend, M, 2002. "The Internet as a new medium for the sciences? The effects of Internet use on traditional scientific communication media among social scientists in Germany," Online Information Review, volume 26, number 5, pp. 307-317. http://dx.doi.org/10.1108/14684520210447877

Ezeani, C.N. \& Igwesi, U. (2012). Using social media for Dynamic Library Service Delivery: The Nigerian Experience. Library Philosophy and Practice. 814. Retrieved 3rd Decemeber, 2013 from http://www.digitalcommons.un/edu/ libphilprac/814.

Fasae, J. K., \& Adegbilero-Iwari, I. (2016). Use of social media by science students in public universities in Southwest Nigeria. The Electronic Library, 34(2), 213-222. doi:10.1108/el-112014-0205

Flanigan, A. and Babchuk, W., 2015. Social media as academic quicksand: A phenomenological study of student experiences in and out of the classroom, p. 40. [pdf]. Available at: < https://www.researchgate.net/profile/Abraham_Flanigan/publication/284137602_Social _media_as_academic_quicksand_A_phenomenological_study_of_student_experiences in_and_out_of_the_classroom/links/56aa2d2208ae2df82166cbee/Social-mediaasacademic-quicksand-A-phenomenological-study-of-student-experiences-in-and-out-oftheclassroom.pdf $>$ (Date of access: 10 December 2017).

Friesen, N. and Lowe, S. (2011), "The questionable promise of social media for education: connective learning and the commercial imperative", Journal of Computer Assisted Learning, Vol. 28 No. 3, pp. 183-194.

Gall, D.P. (2010). Librarian like a Rockstar: using your personal Brand to promote your services and reach distance users. Journal of Library Administration, 50(5 \& 6). Retrieved 3rd Decemeber, 2013 from: http://iruiowa.edu/lib-pubs/58

Giannopoulou, A. (2012). Academic libraries in Greece: Service evaluation and user 
INTERNATIONAL JOURNAL OF ACADEMIC RESEARCH IN BUSINESS AND SOCIAL SCIENCES

Vol. 8, No. 9, Sept. 2018, E-ISSN: 2222-6990 @ 2018 HRMARS

satisfaction. Patra.

[pdf].Available

at:

http://nemertes.lis.upatras.gr/jspui/bitstream/10889/6581/1/MBA\%20\%20\%CE\%92\%CE\%9

9\%CE\%92\%CE\%9B\%CE\%99\%CE\%9F\% \%28final\%29.pdf > (Date of access: 2 December 2017).

Gordhamer, S. (2009), "4 ways Social media is changing Business", retrieved from http://Mashable.com /2009/09/22/Social-MediaBusiness/

Hall, H. (2011), "Relationship and role transformations in social media environments", The Electronic Library, Vol. 29 No. 4, pp. 421-428.

Harrison, R. \& M. Thomas. 2009. Identity in online communities: Social networking sites and language learning. International Journal of Emerging Technologies and Society, 7(2), 109-124.

Hayden, M. and Thompson, J. (2013), "International schools: antecedents, current issues and metaphors for the future", in Pearce, R. (Ed.), International Education and Schools: Moving Beyond the First 40 Years, Bloomsbury Academic, London, pp. 3-24.

Hill, I. (2014), "Internationally-minded schools as cultural artefacts: implications for school leadership", Journal of Research in International Education, Vol. 13 No. 3, pp. 175-189.

Huang, H., Chu, S.K. and Chan, D.Y. (2015), "Interaction between English Speaking and Chinese-speaking user and librarians on social networking sites", Journal of the Association for the Association of Information Science and Technology, Vol. 66 No. 6, pp.

1150-1166.

Hung, H.T. and Yuen, S.C.Y. (2010), "Educational use of social networking technology in higher education", Teaching in Higher Education, Vol. 15 No. 6, pp. 703-714.

Kaplan, A. M., \& Haenlein, M. (2010). Users of the world, unite! The challenges and opportunities of SocialMedia. Business horizons, 53(1), 59-68.

Lewis, B. K. (2009). Social media and strategic communication: Attitudes and perceptions among college students. Public Relations Journal, 4, 1-23.

Loving, M. and Ochoa, M. (2011), "Facebook as a classroom management solution", New Library World, Vol. 112 Nos 3/4, pp. 121-130.

Luo, L., Wang, Y., \& Han, L. (2013). Marketing via social media: A case study. Library Hi Tech, 31(3), 455-466. doi:10.1108/lht-12-2012-0141

Madia, S. A. (2011). Best practices for using social media as a recruitment strategy. Strategic HR Review, 10(6), 19-24. doi:10.1108/14754391111172788

Munir, H.A.S. (1998). Manajemen Pelayanan Umum di Indonesia. Jakarta: Bumi Aksara

Nikola, D., Martina, C. and Ana, K. (2013), "Croatian perspective(s) on the lecturer-student interaction through social media", International Journal of Management Cases, Vol. 15 No. 4, p. 331.

Opeke, R.O. and Onuoha, U.D. (2013), "Librarians use of social networks in Nigeria", PNLA Quarterly, Vol. 77 No. 2, pp. 1-12.

Pierson, V. (2011). Using social media as a feedback mechanism. Beyond the Wire. Retrieved 13th March 2013 from www.instituteofcustomerservice.com

Qualman, E. (2009). Socialnomics: How social media transforms the way we live and do business. John Wiley \& Sons.

Social Network Identity: Facebook, Twitter and Identity Negotiation Theory. (2014). I conference 2014 Proceedings. DOI: 10.9776/14276

Street, C. (2003). Time-saving tips for social media marketing. Retrieved 13th March, 2013 from 
INTERNATIONAL JOURNAL OF ACADEMIC RESEARCH IN BUSINESS AND SOCIAL SCIENCES

Vol. 8, No. 9, Sept. 2018, E-ISSN: 2222-6990 @ 2018 HRMARS

http://socialmediatoday.com

Taylor \& Francis Group. 2014. Use of Social Media by the library current practices and future opportunities: A White Paper From Taylor \& Francis.

Timmis, S. (2012), "Constant companions: instant messaging conversations as sustainable supportive study structures amongst undergraduate peers", Computers \& Education, Vol. 52 No. 1, pp. 3-18.

Umar, H. (2003). Riset Pemasaran dan Perilaku Konsumen. Jakarta: Gramedia Pustaka Utama.

Ziani, A.K. (2015). Using Social Media in the Bahraini 2014 Elections "A Study on a Sample of Young People". Journal New Media and Mass Communication 37: 25-37 